Phys Med Rehabil Clin N Am. 2008 November ; 19(4): 853-x. doi:10.1016/j.pmr.2008.06.002.

\title{
Dysphagia in the Elderly
}

\author{
lanessa A. Humbert, $\mathbf{P h D}^{\mathrm{a}}$ and JoAnne Robbins, $\mathbf{P h D}^{\mathrm{b}, \mathrm{c}}$ \\ aJohns Hopkins University, School of Medicine, Department of Physical Medicine and \\ Rehabilitation \\ bUniversity of Wisconsin School of Medicine and Public Health, Department of Medicine, \\ Madison, WI \\ 'William S. Middleton Memorial Veterans Hospital, Geriatric Research Education and Clinical \\ Center, Madison, WI
}

\section{Keywords}

deglutition; aging; presbyphagia; sensory-motor; neurophysiology

\section{Introduction}

The capacity to effectively and safely swallow or eat is one of the most basic human needs and also can be a great pleasure. Sustaining oneself nutritionally and maintaining adequate hydration while enjoying the process has become intertwined with the activities of society. In fact, older adults look forward to more opportunities to share mealtimes and participate in social interactions including holidays, family occasions and traditions centered on meals and specific foods. Therefore, the loss of the capacity to safely swallow and enjoyably dine can have far reaching implications from sustaining life to quality of life. An ultimate irony is that as we grow older, the ability to swallow, a function very much taken for granted, undergoes changes that increase the risk for disordered swallowing. This occurs with increasing age and exposure to age-related diseases and conditions. Indeed, the loss of the capacity to swallow can have devastating health implications, including nutrition and hydration deficits, especially for older adults.

According to the US Census Bureau, as of July 1, 2005, there were an estimated 78.2 million American baby boomers (those born between 1946 and 1964). In 2006, baby boomers began turning 60 at a rate of about 330 every hour. With the rapid and dramatic growth in the U.S aging population, dysphagia is becoming a national health care burden and concern.

Dysphagia prevalence depends on the specific population sampled, with community dwelling and more independent individuals having rates near 15 percent. Upward of 40 percent of people living in institutionalized settings such as assisted living facilities and

\footnotetext{
${ }^{b, c}$ Corresponding Author for proof and reprints: JoAnne Robbins, PhD, Wm. S. Middleton Memorial Veterans Hospital, 2500 Overlook Terrace GRECC 11G, Madison, WI 53705, (608) 280-7000, (608) 280-7023 FAX, jrobbin2@wisc.edu.

aCoauthor address: Ianessa Humbert, PhD, 98 N. Broadway, Suite 413, Dept. PM\&R, Baltimore, MD 21231, (410) 502-4458, (410) 502-4900 FAX ihumber1@jhmi.edu

Publisher's Disclaimer: This is a PDF file of an unedited manuscript that has been accepted for publication. As a service to our customers we are providing this early version of the manuscript. The manuscript will undergo copyediting, typesetting, and review of the resulting proof before it is published in its final citable form. Please note that during the production process errors may be discovered which could affect the content, and all legal disclaimers that apply to the journal pertain.
} 
nursing homes are dysphagic ${ }^{1}$. With the projected growth of individuals living in nursing homes, there is a compelling need to address dysphagia not only in ambulatory and acute care settings but also in long-term care settings.

\section{Presbyphagia versus Dysphagia}

Although the anatomical, physiological, psychological and functional changes that occur in the dynamic process we refer to as "aging" place older adults at risk for dysphagia; a healthy older adult's swallow is not inherently impaired. Presbyphagia refers to characteristic changes in the swallowing mechanism of otherwise healthy older adults ${ }^{2}$. Clinicians are becoming more aware of the need to distinguish among dysphagia, presbyphagia (an old, yet healthy, swallow) and other related diagnoses in order to avoid over diagnosing and over treating dysphagia. With the increased threat of acute illness, multiple medications, and any number of age-related conditions, older adults are more vulnerable and can cross the line from a healthy older swallow to a person with dysphagia in association with certain perturbations including acute illness, surgery, chemo radiation and other factors. Previous work has focused primarily on the anatomy and physiology of the oropharyngeal swallowing mechanism. Age effects on the temporal evolution of isometric and swallowing pressure $^{2-8}$ indicate a progression of change that, when combined with naturally diminished functional reserve (the resilient ability of the body to adapt to physiological stress ${ }^{9}$ make the older population more susceptible to dysphagia. We review age-related changes in peripheral and central nervous system control of head and neck structures for swallowing in this paper. In addition, we briefly discuss promising strategies for neurorehabilitation of dysphagia that are based upon the recognition that swallowing disruption may, in part, be a manifestation of "sarcopenia", the age-related loss of skeletal muscle mass, organization and strength ${ }^{10}$ as well as age-related changes in sensorimotor acuity and efficiency.

\section{Healthy Swallowing Overview}

Normal oro-pharyngeal swallowing involves closely integrated sensory and motor events that begin with the sight and smell of approaching food until material has safely entered the esophagus. The tongue propels the bolus posteriorly into the pharynx and numerous and varied sensory receptors are stimulated along the way, triggering the pharyngeal swallow ${ }^{11}$. The oral cavity and pharynx contain some of the richest and most diverse sensory receptors of the body, represented by dense intricate nerve supply to the oral cavity, pharynx and larynx. Thus, exact timing of the onset of the pharyngeal swallow is imperative and highly sensory-reliant, such that even a one-second delay, or less, in initiation can result in airway invasion of ingested material ${ }^{12}$. Dysphagia and subsequent aspiration are often the manifestation of a break-down in one or more of the many sensory-motor events that comprise normal swallowing.

\section{Peripheral sensory-motor swallowing}

\section{Age-related changes in specific physiologic parameters}

Sensory-motor function becomes increasingly dampened with senescence throughout the body ${ }^{13-17}$ and rate and extent depend on personal habits (e.g. smoking, alcohol, may increase physiologic change). Structures of the head and neck that are important for normal swallowing also are prone to age-related changes in the peripheral nervous system. These changes have been defined by measures of specific physiologic parameters such as muscle activity, motor-unit density, or assessments of somatosensory perception. Physiologic parameters (i.e reduced pharyngeal pressure) are the basis or cause of age-related changes in general function in swallowing behavior (i.e. slow swallow) between healthy young and old individuals. Anatomical differences in the old include a smaller cross-sectional area of 
masticatory muscles (masseter and medial pterygoid), increased lingual atrophy and fatty infiltration and decreased lingual muscle fiber diameter ${ }^{18,19}$, and atrophied type 1 (slow twitch) fibers in the thyroarytenoid muscle ${ }^{20}$. Beyond anatomical measures, functional changes in muscle activity between young and old include longer muscle activity (twitch prolongation) of the masseter ${ }^{21}$, obicularis oris, supra- and infra-hyoid muscles ${ }^{22}$ and the thyroarytenoid muscle ${ }^{23}$ as well as slower waveforms of the pharyngeal constrictors and lower resting tone of the upper esophageal sphincter ${ }^{24,25}$. Age-related diminishment in strength, mobility and endurance is also evident in the tongue $3,5,26,27$ and lips 28,29 . Sensory function, which is understudied in the swallowing literature, despite its influence on the pharyngeal swallow response, also changes with age and is influenced by declining perception of spatial tactile recognition on the lip and tongue ${ }^{30-32}$, diminished perception of viscosity in the oral cavity ${ }^{33}$, poorer oral stereognosis ${ }^{34,35}$, and reductions in taste perception ${ }^{36,37}$ with increasing age. Although physiological parameters are typically measured at rest, postmortem, or during non-swallowing tasks and may not show immediate or direct clinical relevance to general swallowing function, they can be extrapolated or inferred to age-related changes in swallowing behavior and enhance the global understanding of swallowing abnormalities.

\section{Age-related changes in general sensory-motor swallowing function}

It is generally accepted in published studies that swallowing, as in sensory-motor physiology throughout the body, becomes slower with increasing age $e^{2,38-40}$ beginning in middle age ${ }^{2}$. As well, the pharyngeal swallow response often initiates later in older adults $2,8,41$.

In normal swallowing, the properties of a bolus (i.e. volume, viscosity, temperature) are detected by oro-pharyngeal sensory receptors and are used to guide motor function for swallowing. Increasing bolus volume and viscosity minimizes the delay in pharyngeal swallow initiation ${ }^{42-44}$ and increases laryngeal closure durations ${ }^{2,43}$ in healthy adults. Taste stimuli have also modified swallowing timing ${ }^{45}, 46$, contraction of muscles in the submental region (laryngeal movement) ${ }^{47-49}$, and lingual pressure ${ }^{50}$ compared to a neutral stimulus. To date, much of swallowing research has examined either sensory or motor components with little consideration for the complementary dynamic, despite the intimate synchrony of sensation and movement. Furthermore, given the known multimodal deficiencies in oralpharyngeal sensation, it is no surprise that the swallowing motor response in older adults is less responsive to taste and somatosensory stimuli ${ }^{51}$ compared to a younger cohort. A recent study found that combining sensory stimuli (consistency and taste) minimizes the age differences in motor responses to sensation ${ }^{47}$, likely because older adults benefit from increased exogenous sensory input to drive motor responses.

\section{Central swallowing control}

Dysphagia prevalence increases in advancing age due to more frequent neurological damage or disorders such as stroke ${ }^{52}$, Alzheimer's disease ${ }^{53}$, and Parkinson's disease ${ }^{54}$. Therefore, it has become very important that peripheral differences be investigated along-side central nervous system control. Recent advances in medical technology have facilitated functional brain imaging studies of swallowing, incorporating techniques that include positron emission tomography (PET) ${ }^{55-58}$, magnetoencephalography (MEG) ${ }^{59-63}$, transcranial magnetic stimulation (TMS) $55,64-66$, electroencephalography ${ }^{67-69}$ (EEG), and functional MRI (fMRI) ${ }^{65,70-81}$. Functional MRI is among the fastest growing brain-imaging technologies because it is minimally invasive compared to some other brain imaging systems and is becoming increasingly accessible for research purposes.

In a systematic review of fMRI studies of healthy swallowing ${ }^{82}$, the primary motor cortex was the most prevalent region of activation, followed by the primary sensory cortex. 
Activation was also common in the insula and the anterior cingulate gyrus, but fewer studies found activation in the prefrontal, parietal or temporal lobes consistently or across subjects. Other areas of activation included motor planning areas (supplementary motor area, premotor area), other subcortical regions (internal capsule, thalamus, basal ganglia, putamen, globus palidus) and the cerebellum. All but one of the studies included in this review involved young adults (mean age 35 years). These pioneering fMRI studies of normal swallowing included primarily younger individuals likely because of increased procedure tolerance, task compliance and reduced head movement.

Only one known neuroimaging study (fMRI) examined swallowing in healthy older women and reported similar patterns of activity as in younger individuals in the bilateral sensorymotor cortices, insula/operculum, and cingulate cortex for saliva and water swallows. ${ }^{75}$ Although Martin et al (2006) did not include young adults for a prospective comparison, two separate studies of young women ${ }^{76}$ and old $^{75}$ healthy adults have both shown strong lefthemisphere lateralization for swallowing. An interesting difference was that the older females recruited far more activity for water swallows ${ }^{75}$, primarily in motor planning areas (bilateral middle frontal gyrus and right superior frontal gyrus), while younger females showed more activation for saliva swallows ${ }^{76}$.

When a bolus is being manipulated in the oral cavity, afferent signals enter the brainstem and their representative cranial nerve nuclei, synapsing in the thalamus, and then projecting to sensory specific areas of the cortex ${ }^{83}$. Before the primary motor area can execute movement, the primary sensory cortex sends information to higher-order association areas for a single sensory modality (i.e. temperature, pressure) and for multi-modal processing for attention, motor planning, and memory ${ }^{84}$. These data suggest that the older women required more motor planning for safe swallowing than the young females did. Increased activity in motor planning areas might be the result of reduced peripheral sensory abilities in the oral cavity, requiring motor planning areas to become more active (or work harder) in the absence of adequate stimulation to guide motor movements. Overall, Martin et al has provided the first look into the central control of swallowing in older adults. Future neuroimaging studies should focus on normal aging and swallowing to enhance what is known about peripheral sensory-motor swallowing across the age-span. Furthermore, the effects of increased oropharyngeal sensory stimuli on central control remain uninvestigated. So far, there is only one known experiment where sensation was manipulated (anesthesia) to determine how the brain responds during swallowing (decreased cortical activation in primary sensory-motor regions $)^{85}$.

\section{Changes in skeletal muscle in limbs are similar to head and neck}

Age-related sensory-motor changes have been more extensively studied in the limbs, with similar findings as those described previously in the head and neck. Muscle loss in the limbs, which has been reviewed elsewhere ${ }^{86-88}$, begins in middle age and may be due to loss of muscle fibers ${ }^{89-92}$, fewer motor units ${ }^{14,93-95}$ and progressive denervation and changes in nerve conduction ${ }^{17,96}$. Sensory losses in the extremities with age involve declining ability to detect vibratory stimulation ${ }^{97}$ and spatial tactile discrimination (particularly in the hands and feet). These sensory-motor losses translate into gross functional deficiencies in manual dexterity ${ }^{13,98}$, limb strength ${ }^{15,99,100}$ and walking speed $^{16,101,102}$.

Peripheral changes to limb anatomy and function occur along-side increased neural activation during limb movement in old compared to young within certain brain regions ${ }^{103-107}$. Heuninckx et al (2008) recently investigated whether the elaborate cortical responses in the old is related to compensation for increased task effort or dedifferentiation 
(age-related inability to activate specialized neural mechanisms unrelated to task performance) using a complex interlimb coordination task. Results showed that additional cortical recruitment (primary sensory-motor cortices and motor planning areas) was positively correlated with increased motor success within older adults, but not in younger adults. Therefore, the over-activation in the old for motor tasks compared to young is consistent with the compensation hypothesis, where task-related changes are positively correlated with neural activation.

Although some discourage extrapolating limb muscle function to head and neck musculature ${ }^{108}$, these reports of over-activation in the brain relative to limb motor function may be useful leads toward hypotheses for swallowing studies of neurophysiology in healthy aging. Future studies of the effects of age on swallowing neurophysiology should determine whether age-related differences in peripheral movement (i.e. slower swallows in older individuals ${ }^{2}$ ) appear to occur along side differences in neural control of swallowing. Furthermore, incorporating effortful swallowing might convey information about increased neural activation with increased effort with a swallowing task in elders. Overall, knowledge of swallowing neurophysiology in healthy aging is becoming more important as we approach the possibility of using neuroimaging techniques for clinical purposes to understand dysphagia. Without age-matched controls, dysphagic patients with decreased brain activation for swallowing might show "normal" activation compared to young healthy adults, who normally have less activation than their older counterparts.

\section{Therapy}

With advancing age, lean protein tissue diminishes, contributing to the loss of muscle protein mass, while adipose tissue increases in skeletal muscle of the limbs ${ }^{109}$. Many studies are showing increased rates of muscle protein synthesis with acute resistance exercise and resistance exercise training programs in middle aged and frail older adults ${ }^{110-112}$. Functional gains with exercise include upper- and lower body strength and balance, agility and endurance ${ }^{113-117}$.

In traditional swallowing, compensatory treatment strategies are used to alter the flow of material in the pharynx. Chin tuck and head rotation decreased choking during swallowing immediately ${ }^{118}$, reduced aspiration in $81 \%$ of patients ${ }^{119}$, and reduced aspiration in $25 \%$ of patients who used it for all volumes swallowed ${ }^{120}$. Head rotation was $20-75 \%$ effective in reducing aspiration ${ }^{120-122}$, and increasing the duration of laryngeal elevation ${ }^{122}$. A large multisite randomized clinical trial recently indicated the need to better understand the relationship between material properties of thickened fluids often provided to elders who aspirate thin fluids relative to changes in health status. The investigators conclude that the future need is to examine efficacy of a combination of physiologically sound interventions relative to solely modifying diet (based on a cohort of 512 research participants) $)^{123,124}$, particularly in the older populations with dysphagia secondary to dementia or Parkinson disease. Despite some success with compensatory maneuvers, and modifying food consistencies, these techniques offer patients little in the way of rehabilitation for functional swallowing. Research to date primarily has focused on non-swallow and enhanced swallowing (i.e. effortful swallowing ${ }^{125}$ ) motor exercises to increase muscle strength and range of motion in oropharyngeal structures. Exercise has shown to be effective in increasing strength of the tongue and improving functional swallowing in the healthy $\operatorname{old}^{3,5,126,127}$ and in dysphagic individuals ${ }^{128,129}$.

Sensory modalities have garnered little attention for long-term swallowing treatment, despite many reports of positive effects of increased intra-oral stimulation (i.e. taste, texture, temperature, viscosity) on swallowing biomechanics and bolus flow kinematics $45,47-49,130$. 
In addition to intra-oral stimulation, electrical stimulation to the submental and neck regions at low sensory threshold levels reduced aspiration frequency and residue amounts in individuals with chronic pharyngeal dysphagia ${ }^{131}$. Each of these sensory modalities is exogenous or externally-cued forms of stimulation to improve a motor response.

Endogenous or internally cued stimulation involves increased attention to a task, resulting in top-down initiation and increased neural activation of motor planning and execution areas of the cortex during a motor task in healthy adults ${ }^{132}$. All forms of increased sensory stimulation or attention to a task should be incorporated into swallowing therapy, especially given known diminishment in oropharyngeal sensation, attention and memory in older adults.

Sensory-based swallowing therapies that aim to increase a motor response (i.e. sour or cold bolus), rather than modify bolus flow (i.e. thickened liquids) might receive little attention because they are not routinely included in assessments of swallowing function. Also, their usefulness has not been researched over the long-term, despite the likelihood that adaptation to a sensory stimulus might gradually decrease the effect of stimulus on the motor response. Some studies have reported oral and tongue sensory assessments ${ }^{133}, 134$; these could be included in swallowing assessments. Also, older participants demonstrated more difficulty with taste components of the sensory assessments compared to oral somatosensory measures ${ }^{135}$. Sensory assessments of the oropharynx for swallowing to understand healthy aging might be limited by the use of psychophysical measures (relationship between physical stimuli and their subjective percepts), where the clinician relies heavily on subjective reports of intensity for stimuli. Thus, cognitive differences may affect the accuracy of responses. In addition, assessing sensory ability requires knowledge and expertise to create, conduct and interpret valid and reliable measures of oropharyngeal sensation. Therefore, as in many clinical and research foci of swallowing, multidisciplinary collaborations will be necessary to derive useful sensory assessments for swallowing.

As medical technology for neuroimaging becomes more useful and available, more neurorehabilitation treatments will be examined for both peripheral and central changes in disordered populations as a means of determining effectiveness ${ }^{136}$. With impending changes, it is imperative that sensory-motor abilities in healthy older adults are thoroughly researched so that correlations between the brain and swallowing biomechanics can be interpreted accurately for comparison to the dysphagic population.

\section{References}

1. Barczi SRSP, Robbins J. How should dysphagia care of older adults differ? Establishing optimal practice patterns. Semin Speech Lang. 2000; 21(4):347-361. [PubMed: 11085258]

2. Robbins J, Hamilton JW, Lof GL, Kempster GB. Oropharyngeal swallowing in normal adults of different ages. Gastroenterology. 1992 Sep; 103(3):823-829. [PubMed: 1499933]

3. Nicosia MA, Hind JA, Roecker EB, et al. Age effects on the temporal evolution of isometric and swallowing pressure. J Gerontol A Biol Sci Med Sci. 2000 Nov; 55(11):M634-M640. [PubMed: 11078092]

4. Robbins J, Coyle J, Rosenbek J, Roecker E, Wood J. Differentiation of normal and abnormal airway protection during swallowing using the penetration-aspiration scale. Dysphagia. 1999 Fall;14(4): 228-232. [PubMed: 10467048]

5. Robbins J, Levine R, Wood J, Roecker EB, Luschei E. Age effects on lingual pressure generation as a risk factor for dysphagia. J Gerontol A Biol Sci Med Sci. 1995 Sep; 50(5):M257-M262. [PubMed: 7671027]

6. Shaw DWCI, Dent J, et al. Age influence oropharyngeal and upper esophageal sphincter function during swallowing. Gastroenterology. 1990; 98(A390) 
7. Shaw DWCI, Gabb M, et al. Influence of normal aging on oropharyngeal and upper esophageal sphincter function during swallow. Am J Physiol. 1995; L68:G389-G390. [PubMed: 7900799]

8. Tracy JF, Logemann JA, Kahrilas PJ, Jacob P, Kobara M, Krugler C. Preliminary observations on the effects of age on oropharyngeal deglutition. Dysphagia. 1989; 4(2):90-94. [PubMed: 2640185]

9. Pendergast DR, Fisher NM, Calkins E. Cardiovascular, neuromuscular, and metabolic alterations with age leading to frailty. J Gerontol. 1993 Sep.48:61-67. Spec No. [PubMed: 8409243]

10. Rosenberg IH. Sarcopenia: origins and clinical relevance. J Nutr. 1997 May; 127(5 Suppl):990S991S. [PubMed: 9164280]

11. Miller AJ. Oral and pharyngeal reflexes in the mammalian nervous system: their diverse range in complexity and the pivotal role of the tongue. Crit Rev Oral Biol Med. 2002; 13(5):409-425. [PubMed: 12393760]

12. Perlman AL, Booth BM, Grayhack JP. Videofluoroscopic predictors of aspiration in patients with oropharyngeal dysphagia. Dysphagia. 1994 Spring;9(2):90-95. [PubMed: 8005013]

13. Aniansson A, Rundgren A, Sperling L. Evaluation of functional capacity in activities of daily living in 70-year-old men and women. Scand J Rehabil Med. 1980; 12(4):145-154. [PubMed: 7268322]

14. Brown WF. A method for estimating the number of motor units in thenar muscles and the changes in motor unit count with ageing. J Neurol Neurosurg Psychiatry. 1972 Dec; 35(6):845-852. [PubMed: 4647858]

15. Danneskiold-Samsoe B, Kofod V, Munter J, Grimby G, Schnohr P, Jensen G. Muscle strength and functional capacity in 78-81-year-old men and women. Eur J Appl Physiol Occup Physiol. 1984; 52(3):310-314. [PubMed: 6539684]

16. Himann JE, Cunningham DA, Rechnitzer PA, Paterson DH. Age-related changes in speed of walking. Med Sci Sports Exerc. 1988 Apr; 20(2):161-166. [PubMed: 3367751]

17. LaFratta CW, Canestrari R. A comparison of sensory and motor nerve conduction velocities as related to age. Arch Phys Med Rehabil. 1966 May; 47(5):286-290. [PubMed: 5934875]

18. Bassler R. Histopathology of different types of atrophy of the human tongue. Pathol Res Pract. 1987 Feb; 182(1):87-97. [PubMed: 3588408]

19. Nakayama M. [Histological study on aging changes in the human tongue]. Nippon Jibiinkoka Gakkai Kaiho. 1991 Apr; 94(4):541-555. [PubMed: 2061734]

20. Malmgren LT, Fisher PJ, Bookman LM, Uno T. Age-related changes in muscle fiber types in the human thyroarytenoid muscle: an immunohistochemical and stereological study using confocal laser scanning microscopy. Otolaryngol Head Neck Surg. 1999 Oct; 121(4):441-451. [PubMed: 10504602]

21. Newton J, Yemm R. Age changes in contractile properties of masseter muscle in man. J Oral Rehab. 1990; 17:204-205.

22. Vaiman M, Eviatar E, Segal S. Surface electromyographic studies of swallowing in normal subjects: a review of 440 adults. Report 1. Quantitative data: timing measures. Otolaryngol Head Neck Surg. 2004 Oct; 131(4):548-555. [PubMed: 15467634]

23. Takeda N, Thomas GR, Ludlow CL. Aging effects on motor units in the human thyroarytenoid muscle. Laryngoscope. 2000 Jun; 110(6):1018-1025. [PubMed: 10852524]

24. Bardan E, Xie P, Brasseur J, et al. Effect of ageing on the upper and lower oesophageal sphincters. Eur J Gastroenterol Hepatol. 2000 Nov; 12(11):1221-1225. [PubMed: 11111779]

25. McKee GJ, Johnston BT, McBride GB, Primrose WJ. Does age or sex affect pharyngeal swallowing? Clin Otolaryngol Allied Sci. 1998 Apr; 23(2):100-106. [PubMed: 9597278]

26. Crow HC, Ship JA. Tongue strength and endurance in different aged individuals. J Gerontol A Biol Sci Med Sci. 1996 Sep; 51(5):M247-M250. [PubMed: 8808997]

27. Price PA, Darvell BW. Force and mobility in the ageing human tongue. Med J Aust. 1981 Jan 24; 1(2):75-78. [PubMed: 7231253]

28. Wohlert AB. Reflex responses of lip muscles in young and older women. J Speech Hear Res. 1996 Jun; 39(3):578-589. [PubMed: 8783136]

29. Wohlert AB. Perioral muscle activity in young and older adults during speech and nonspeech tasks. J Speech Hear Res. 1996 Aug; 39(4):761-770. [PubMed: 8844556] 
30. Johnson KO, Phillips JR. Tactile spatial resolution. I. Two-point discrimination, gap detection, grating resolution, and letter recognition. J Neurophysiol. 1981 Dec; 46(6):1177-1192. [PubMed: 7320742]

31. Stevens JC, Choo KK. Spatial acuity of the body surface over the life span. Somatosens Mot Res. 1996; 13(2):153-166. [PubMed: 8844964]

32. Wohlert AB. Tactile perception of spatial stimuli on the lip surface by young and older adults. J Speech Hear Res. 1996 Dec; 39(6):1191-1198. [PubMed: 8959604]

33. Smith CH, Logemann JA, Burghardt WR, Zecker SG, Rademaker AW. Oral and oropharyngeal perceptions of fluid viscosity across the age span. Dysphagia. 2006 Oct; 21(4):209-217. [PubMed: 17203333]

34. Calhoun KH, Gibson B, Hartley L, Minton J, Hokanson JA. Age-related changes in oral sensation. Laryngoscope. 1992 Feb; 102(2):109-116. [PubMed: 1738279]

35. Williams WN, La Pointe LL. Intra-oral recognition of geometric forms by normal subjects. Percept Mot Skills. 1971 Apr; 32(2):419-426. [PubMed: 5089065]

36. Bartoshuk LM. Taste. Robust across the age span? Ann N Y Acad Sci. 1989; 561:65-75. [PubMed: 2735690]

37. Chauhan J, Hawrysh ZJ. Suprathreshold sour taste intensity and pleasantness perception with age. Physiol Behav. 1988; 43(5):601-607. [PubMed: 3200915]

38. Cook IJ, Weltman MD, Wallace K, et al. Influence of aging on oral-pharyngeal bolus transit and clearance during swallowing: scintigraphic study. Am J Physiol. 1994 Jun; 266(6 Pt 1):G972G977. [PubMed: 8023945]

39. Dejaeger E, Pelemans W. Swallowing and the duration of the hyoid movement in normal adults of different ages. Aging (Milano). 1996 Apr; 8(2):130-134. [PubMed: 8737612]

40. Logemann JA, Pauloski BR, Rademaker AW, Kahrilas PJ. Oropharyngeal swallow in younger and older women: videofluoroscopic analysis. J Speech Lang Hear Res. 2002 Jun; 45(3):434-445. [PubMed: 12068997]

41. Logemann JA, Pauloski BR, Rademaker AW, Colangelo LA, Kahrilas PJ, Smith CH. Temporal and biomechanical characteristics of oropharyngeal swallow in younger and older men. J Speech Lang Hear Res. 2000 Oct; 43(5):1264-1274. [PubMed: 11063246]

42. Bisch EM, Logemann JA, Rademaker AW, Kahrilas PJ, Lazarus CL. Pharyngeal effects of bolus volume, viscosity, and temperature in patients with dysphagia resulting from neurologic impairment and in normal subjects. J Speech Hear Res. 1994 Oct; 37(5):1041-1059. [PubMed: 7823550]

43. Lazarus CL, Logemann JA, Rademaker AW, et al. Effects of bolus volume, viscosity, and repeated swallows in nonstroke subjects and stroke patients. Arch Phys Med Rehabil. 1993 Oct; 74(10): 1066-1070. [PubMed: 8215858]

44. Logemann JA, Kahrilas PJ, Cheng J, et al. Closure mechanisms of laryngeal vestibule during swallow. Am J Physiol. 1992 Feb; 262(2 Pt 1):G338-G344. [PubMed: 1539666]

45. Chee C, Arshad S, Singh S, Mistry S, Hamdy S. The influence of chemical gustatory stimuli and oral anaesthesia on healthy human pharyngeal swallowing. Chem Senses. 2005 Jun; 30(5):393400. [PubMed: 15829608]

46. Hamdy S, Jilani S, Price V, Parker C, Hall N, Power M. Modulation of human swallowing behaviour by thermal and chemical stimulation in health and after brain injury. Neurogastroenterol Motil. 2003 Feb; 15(1):69-77. [PubMed: 12588471]

47. Ding R, Logemann JA, Larson CR, Rademaker AW. The effects of taste and consistency on swallow physiology in younger and older healthy individuals: a surface electromyographic study. J Speech Lang Hear Res. 2003 Aug; 46(4):977-989. [PubMed: 12959474]

48. Leow LP, Huckabee ML, Sharma S, Tooley TP. The influence of taste on swallowing apnea, oral preparation time, and duration and amplitude of submental muscle contraction. Chem Senses. 2007 Feb; 32(2):119-128. [PubMed: 17071940]

49. Palmer PM, McCulloch TM, Jaffe D, Neel AT. Effects of a sour bolus on the intramuscular electromyographic (EMG) activity of muscles in the submental region. Dysphagia. 2005 Summer; 20(3):210-217. [PubMed: 16362509] 
50. Pelletier CA, Dhanaraj GE. The effect of taste and palatability on lingual swallowing pressure. Dysphagia. 2006 Apr; 21(2):121-128. [PubMed: 16703444]

51. Shaker R, Ren J, Bardan E, et al. Pharyngoglottal closure reflex: characterization in healthy young, elderly and dysphagic patients with predeglutitive aspiration. Gerontology. 2003 Jan-Feb; 49(1): 12-20. [PubMed: 12457045]

52. Robbins J, Levine RL, Maser A, Rosenbek JC, Kempster GB. Swallowing after unilateral stroke of the cerebral cortex. Arch Phys Med Rehabil. 1993 Dec; 74(12):1295-1300. [PubMed: 8259895]

53. Priefer BA, Robbins J. Eating changes in mild-stage Alzheimer's disease: a pilot study. Dysphagia. 1997 Fall;12(4):212-221. [PubMed: 9294942]

54. Robbins JA, Logemann JA, Kirshner HS. Swallowing and speech production in Parkinson's disease. Ann Neurol. 1986 Mar; 19(3):283-287. [PubMed: 3963773]

55. Hamdy S, Rothwell JC, Brooks DJ, Bailey D, Aziz Q, Thompson DG. Identification of the cerebral loci processing human swallowing with H2(15)O PET activation. J Neurophysiol. 1999 Apr; 81(4):1917-1926. [PubMed: 10200226]

56. Harris ML, Julyan P, Kulkarni B, et al. Mapping metabolic brain activation during human volitional swallowing: a positron emission tomography study using [18F]fluorodeoxyglucose. J Cereb Blood Flow Metab. 2005 Apr; 25(4):520-526. [PubMed: 15689960]

57. Raichle ME, Fiez JA, Videen TO, et al. Practice-related changes in human brain functional anatomy during nonmotor learning. Cereb Cortex. 1994 Jan-Feb; 4(1):8-26. [PubMed: 8180494]

58. Zald DH, Pardo JV. The functional neuroanatomy of voluntary swallowing. Ann Neurol. 1999 Sep; 46(3):281-286. [PubMed: 10482257]

59. Abe S, Wantanabe Y, Shintani M, et al. Magnetoencephalographic study of the starting point of voluntary swallowing. Cranio. 2003 Jan; 21(1):46-49. [PubMed: 12555931]

60. Dziewas R, Soros P, Ishii R, et al. Neuroimaging evidence for cortical involvement in the preparation and in the act of swallowing. Neuroimage. 2003 Sep; 20(1):135-144. [PubMed: 14527576]

61. Furlong PL, Hobson AR, Aziz Q, et al. Dissociating the spatio-temporal characteristics of cortical neuronal activity associated with human volitional swallowing in the healthy adult brain. Neuroimage. 2004 Aug; 22(4):1447-1455. [PubMed: 15275902]

62. Loose R, Hamdy S, Enck P. Magnetoencephalographic response characteristics associated with tongue movement. Dysphagia. 2001 Summer;16(3):183-185. [PubMed: 11453564]

63. Watanabe Y, Abe S, Ishikawa T, Yamada Y, Yamane GY. Cortical regulation during the early stage of initiation of voluntary swallowing in humans. Dysphagia. 2004 Spring;19(2):100-108. [PubMed: 15382798]

64. Ertekin C, Turman B, Tarlaci S, et al. Cricopharyngeal sphincter muscle responses to transcranial magnetic stimulation in normal subjects and in patients with dysphagia. Clin Neurophysiol. 2001 Jan; 112(1):86-94. [PubMed: 11137665]

65. Fraser C, Power M, Hamdy S, et al. Driving plasticity in human adult motor cortex is associated with improved motor function after brain injury. Neuron. 2002 May 30; 34(5):831-840. [PubMed: 12062028]

66. Rodel RM, Laskawi R, Markus H. Tongue representation in the lateral cortical motor region of the human brain as assessed by transcranial magnetic stimulation. Ann Otol Rhinol Laryngol. 2003 Jan; 112(1):71-76. [PubMed: 12537062]

67. Hiraoka K. Movement-related cortical potentials associated with saliva and water bolus swallowing. Dysphagia. 2004 Summer;19(3):155-159. [PubMed: 15383944]

68. Huckabee ML, Deecke L, Cannito MP, Gould HJ, Mayr W. Cortical control mechanisms in volitional swallowing: the Bereitschaftspotential. Brain Topogr. 2003 Fall;16(1):3-17. [PubMed: 14587965]

69. Satow T, Ikeda A, Yamamoto J, et al. Role of primary sensorimotor cortex and supplementary motor area in volitional swallowing: a movement-related cortical potential study. Am J Physiol Gastrointest Liver Physiol. 2004 Aug; 287(2):G459-G470. [PubMed: 14701719]

70. Birn RM, Bandettini PA, Cox RW, Shaker R. Event-related fMRI of tasks involving brief motion. Hum Brain Mapp. 1999; 7(2):106-114. [PubMed: 9950068] 
71. Hamdy S, Mikulis DJ, Crawley A, et al. Cortical activation during human volitional swallowing: an event-related fMRI study. Am J Physiol. 1999 Jul; 277(1 Pt 1):G219-G225. [PubMed: 10409170]

72. Kern M, Birn R, Jaradeh S, et al. Swallow-related cerebral cortical activity maps are not specific to deglutition. Am J Physiol Gastrointest Liver Physiol. 2001 Apr; 280(4):G531-G538. [PubMed: 11254478]

73. Kern MK, Jaradeh S, Arndorfer RC, Shaker R. Cerebral cortical representation of reflexive and volitional swallowing in humans. Am J Physiol Gastrointest Liver Physiol. 2001 Mar; 280(3):G354-G360. [PubMed: 11171617]

74. Komisaruk BR, Mosier KM, Liu WC, et al. Functional localization of brainstem and cervical spinal cord nuclei in humans with fMRI. AJNR Am J Neuroradiol. 2002 Apr; 23(4):609-617. [PubMed: 11950653]

75. Martin R, Barr A, Macintosh B, et al. Cerebral cortical processing of swallowing in older adults. Exp Brain Res. 2006 Aug 5.

76. Martin RE, MacIntosh BJ, Smith RC, et al. Cerebral areas processing swallowing and tongue movement are overlapping but distinct: a functional magnetic resonance imaging study. $\mathrm{J}$ Neurophysiol. 2004 Oct; 92(4):2428-2443. [PubMed: 15163677]

77. Mosier K, Bereznaya I. Parallel cortical networks for volitional control of swallowing in humans. Exp Brain Res. 2001 Oct; 140(3):280-289. [PubMed: 11681303]

78. Mosier K, Patel R, Liu WC, Kalnin A, Maldjian J, Baredes S. Cortical representation of swallowing in normal adults: functional implications. Laryngoscope. 1999 Sep; 109(9):14171423. [PubMed: 10499047]

79. Mosier KM, Liu WC, Maldjian JA, Shah R, Modi B. Lateralization of cortical function in swallowing: a functional MR imaging study. AJNR Am J Neuroradiol. 1999 Sep; 20(8):15201526. [PubMed: 10512240]

80. Suzuki M, Asada Y, Ito J, Hayashi K, Inoue H, Kitano H. Activation of cerebellum and basal ganglia on volitional swallowing detected by functional magnetic resonance imaging. Dysphagia. 2003 Spring;18(2):71-77. [PubMed: 12825899]

81. Toogood JA, Barr AM, Stevens TK, Gati JS, Menon RS, Martin RE. Discrete functional contributions of cerebral cortical foci in voluntary swallowing: a functional magnetic resonance imaging (fMRI) "Go, No-Go" study. Exp Brain Res. 2005 Feb; 161(1):81-90. [PubMed: 15536553]

82. Humbert IA, Robbins J. Normal swallowing and functional magnetic resonance imaging: a systematic review. Dysphagia. 2007 Jul; 22(3):266-275. [PubMed: 17440775]

83. Kandel, ER.; Schwartz, JH.; Jessell, TM. Principles of neural science. 4th ed.. New York: McGraw-Hill, Health Professions Division; 2000.

84. Kandel, E.; Schwartz, J. Principles of Neuroscience. New York: McGraw Hill; 2000.

85. Teismann IK, Steinstraeter O, Stoeckigt K, et al. Functional oropharyngeal sensory disruption interferes with the cortical control of swallowing. BMC Neurosci. 2007; 8:62. [PubMed: 17678546]

86. Doherty TJ, Vandervoort AA, Brown WF. Effects of ageing on the motor unit: a brief review. Can J Appl Physiol. 1993 Dec; 18(4):331-358. [PubMed: 8275048]

87. Grimby G. Muscle performance and structure in the elderly as studied cross-sectionally and longitudinally. J Gerontol A Biol Sci Med Sci. 1995 Nov; 50(Spec No):17-22. [PubMed: 7493212]

88. Young A. Ageing and physiological functions. Philos Trans R Soc Lond B Biol Sci. 1997 Dec 29; 352(1363):1837-1843. [PubMed: 9460068]

89. Faulkner JA, Brooks SV, Zerba E. Skeletal muscle weakness and fatigue in old age: underlying mechanisms. Annu Rev Gerontol Geriatr. 1990; 10:147-166. [PubMed: 2102709]

90. Klitgaard H, Mantoni M, Schiaffino S, et al. Function, morphology and protein expression of ageing skeletal muscle: a cross-sectional study of elderly men with different training backgrounds. Acta Physiol Scand. 1990 Sep; 140(1):41-54. [PubMed: 2275404] 
91. Lexell J, Henriksson-Larsen K, Winblad B, Sjostrom M. Distribution of different fiber types in human skeletal muscles: effects of aging studied in whole muscle cross sections. Muscle Nerve. 1983 Oct; 6(8):588-595. [PubMed: 6646161]

92. Lexell J, Taylor CC, Sjostrom M. What is the cause of the ageing atrophy? Total number, size and proportion of different fiber types studied in whole vastus lateralis muscle from 15- to 83-year-old men. J Neurol Sci. 1988 Apr; 84(2-3):275-294. [PubMed: 3379447]

93. Campbell MJ, McComas AJ, Petito F. Physiological changes in ageing muscles. J Neurol Neurosurg Psychiatry. 1973 Apr; 36(2):174-182. [PubMed: 4708452]

94. Doherty TJ, Brown WF. The estimated numbers and relative sizes of thenar motor units as selected by multiple point stimulation in young and older adults. Muscle Nerve. 1993 Apr; 16(4):355-366. [PubMed: 8455648]

95. Doherty TJ, Vandervoort AA, Taylor AW, Brown WF. Effects of motor unit losses on strength in older men and women. J Appl Physiol. 1993 Feb; 74(2):868-874. [PubMed: 8458808]

96. Lexell J, Downham DY. The occurrence of fibre-type grouping in healthy human muscle: a quantitative study of cross-sections of whole vastus lateralis from men between 15 and 83 years. Acta Neuropathol. 1991; 81(4):377-381. [PubMed: 2028741]

97. de Neeling JN, Beks PJ, Bertelsmann FW, Heine RJ, Bouter LM. Sensory thresholds in older adults: reproducibility and reference values. Muscle Nerve. 1994 Apr; 17(4):454-461. [PubMed: 8170493]

98. Lundgren-Lindquist B, Sperling L. Functional studies in 79-year-olds. II. Upper extremity function. Scand J Rehabil Med. 1983; 15(3):117-123. [PubMed: 6635601]

99. Frontera WR, Hughes VA, Lutz KJ, Evans WJ. A cross-sectional study of muscle strength and mass in 45- to 78-yr-old men and women. J Appl Physiol. 1991 Aug; 71(2):644-650. [PubMed: 1938738]

100. Johnson T. Age-related differences in isometric and dynamic strength and endurance. Phys Ther. 1982 Jul; 62(7):985-989. [PubMed: 7089062]

101. Bendall MJ, Bassey EJ, Pearson MB. Factors affecting walking speed of elderly people. Age Ageing. 1989 Sep; 18(5):327-332. [PubMed: 2603841]

102. Samson MM, Crowe A, de Vreede PL, Dessens JA, Duursma SA, Verhaar HJ. Differences in gait parameters at a preferred walking speed in healthy subjects due to age, height and body weight. Aging (Milano). 2001 Feb; 13(1):16-21. [PubMed: 11292147]

103. Calautti C, Serrati C, Baron JC. Effects of age on brain activation during auditory-cued thumb-toindex opposition: A positron emission tomography study. Stroke. 2001 Jan; 32(1):139-146. [PubMed: 11136929]

104. Heuninckx S, Wenderoth N, Debaere F, Peeters R, Swinnen SP. Neural basis of aging: the penetration of cognition into action control. J Neurosci. 2005 Jul 20; 25(29):6787-6796. [PubMed: 16033888]

105. Hutchinson S, Kobayashi M, Horkan CM, Pascual-Leone A, Alexander MP, Schlaug G. Agerelated differences in movement representation. Neuroimage. 2002 Dec; 17(4):1720-1728. [PubMed: 12498746]

106. Mattay VS, Fera F, Tessitore A, et al. Neurophysiological correlates of age-related changes in human motor function. Neurology. 2002 Feb 26; 58(4):630-635. [PubMed: 11865144]

107. Ward NS, Frackowiak RS. Age-related changes in the neural correlates of motor performance. Brain. 2003 Apr; 126(Pt 4):873-888. [PubMed: 12615645]

108. McComas AJ. Oro-facial muscles: internal structure, function and ageing. Gerodontology. 1998; 15(1):3-14. [PubMed: 10530166]

109. Cohn SH, Vartsky D, Yasumura S, et al. Compartmental body composition based on total-body nitrogen, potassium, and calcium. Am J Physiol. 1980 Dec; 239(6):E524-E530. [PubMed: 7446727]

110. Hasten DL, Pak-Loduca J, Obert KA, Yarasheski KE. Resistance exercise acutely increases MHC and mixed muscle protein synthesis rates in 78-84 and 23-32 yr olds. Am J Physiol Endocrinol Metab. 2000 Apr; 278(4):E620-E626. [PubMed: 10751194] 
111. Schulte JN, Yarasheski KE. Effects of resistance training on the rate of muscle protein synthesis in frail elderly people. Int J Sport Nutr Exerc Metab. 2001 Dec.11 Suppl:S111-S118. [PubMed: 11915909]

112. Yarasheski KE, Pak-Loduca J, Hasten DL, Obert KA, Brown MB, Sinacore DR. Resistance exercise training increases mixed muscle protein synthesis rate in frail women and men $>/=76 \mathrm{yr}$ old. Am J Physiol. 1999 Jul; 277(1 Pt 1):E118-E125. [PubMed: 10409135]

113. Helbostad JL, Sletvold O, Moe-Nilssen R. Effects of home exercises and group training on functional abilities in home-dwelling older persons with mobility and balance problems. A randomized study. Aging Clin Exp Res. 2004 Apr; 16(2):113-121. [PubMed: 15195985]

114. Judge JO, Lindsey C, Underwood M, Winsemius D. Balance improvements in older women: effects of exercise training. Phys Ther. 1993 Apr; 73(4):254-262. discussion 263-255. [PubMed: 8456144]

115. Takeshima N, Rogers NL, Rogers ME, Islam MM, Koizumi D, Lee S. Functional fitness gain varies in older adults depending on exercise mode. Med Sci Sports Exerc. 2007 Nov; 39(11): 2036-2043. [PubMed: 17986913]

116. Taylor-Piliae RE, Haskell WL, Stotts NA, Froelicher ES. Improvement in balance, strength, and flexibility after 12 weeks of Tai chi exercise in ethnic Chinese adults with cardiovascular disease risk factors. Altern Ther Health Med. 2006 Mar-Apr; 12(2):50-58. [PubMed: 16541997]

117. Toraman NF, Erman A, Agyar E. Effects of multicomponent training on functional fitness in older adults. J Aging Phys Act. 2004 Oct; 12(4):538-553. [PubMed: 15851825]

118. Bryant M. Biofeedback in the treatment of a selected dysphagic patient. Dysphagia. 1991; 6(3): 140-144. [PubMed: 1914542]

119. Lewin JS, Hebert TM, Putnam JB Jr, DuBrow RA. Experience with the chin tuck maneuver in postesophagectomy aspirators. Dysphagia. 2001 Summer;16(3):216-219. [PubMed: 11453570]

120. Rasley A, Logemann JA, Kahrilas PJ, Rademaker AW, Pauloski BR, Dodds WJ. Prevention of barium aspiration during videofluoroscopic swallowing studies: value of change in posture. AJR Am J Roentgenol. 1993 May; 160(5):1005-1009. [PubMed: 8470567]

121. Logemann JA, Rademaker AW, Pauloski BR, Kahrilas PJ. Effects of postural change on aspiration in head and neck surgical patients. Otolaryngol Head Neck Surg. 1994 Feb; 110(2): 222-227. [PubMed: 8108157]

122. Logemann JA, Kahrilas PJ. Relearning to swallow after stroke--application of maneuvers and indirect biofeedback: a case study. Neurology. 1990 Jul; 40(7):1136-1138. [PubMed: 2356016]

123. Logemann JA, Gensler G, Robbins J, et al. A randomized study of three interventions for aspiration of thin liquids in patients with dementia or Parkinson's disease. J Speech Lang Hear Res. 2008 Feb; 51(1):173-183. [PubMed: 18230864]

124. Robbins JAGG, Hind JA, Logemann JA, Lindblad AS, Brandt D, Kosek S, Dikeman K, Kazandjian M, Gramigna G, McGarvey-Toler S, Miller Gardner P. Comparison of Two Interventions for Liquid Aspiration on Pneumonia Incidence: A Randomized Controlled Trial. Annals of Internal Medicine. Annals of Internal Medicine. In Press.

125. Hind JA, Nicosia MA, Roecker EB, Carnes ML, Robbins J. Comparison of effortful and noneffortful swallows in healthy middle-aged and older adults. Arch Phys Med Rehabil. 2001 Dec; 82(12):1661-1665. [PubMed: 11733879]

126. Easterling C, Grande B, Kern M, Sears K, Shaker R. Attaining and maintaining isometric and isokinetic goals of the Shaker exercise. Dysphagia. 2005 Spring;20(2):133-138. [PubMed: 16172822]

127. Robbins J, Gangnon RE, Theis SM, Kays SA, Hewitt AL, Hind JA. The effects of lingual exercise on swallowing in older adults. J Am Geriatr Soc. 2005 Sep; 53(9):1483-1489. [PubMed: 16137276]

128. Robbins J, Kays SA, Gangnon RE, et al. The effects of lingual exercise in stroke patients with dysphagia. Arch Phys Med Rehabil. 2007 Feb; 88(2):150-158. [PubMed: 17270511]

129. Shaker R, Easterling C, Kern M, et al. Rehabilitation of swallowing by exercise in tube-fed patients with pharyngeal dysphagia secondary to abnormal UES opening. Gastroenterology. 2002 May; 122(5):1314-1321. [PubMed: 11984518] 
130. Logemann JA, Pauloski BR, Colangelo L, Lazarus C, Fujiu M, Kahrilas PJ. Effects of a sour bolus on oropharyngeal swallowing measures in patients with neurogenic dysphagia. J Speech Hear Res. 1995 Jun; 38(3):556-563. [PubMed: 7674647]

131. Ludlow CL, Humbert I, Saxon K, Poletto C, Sonies B, Crujido L. Effects of surface electrical stimulation both at rest and during swallowing in chronic pharyngeal Dysphagia. Dysphagia. 2007 Jan; 22(1):1-10. [PubMed: 16718620]

132. Jenkins IH, Jahanshahi M, Jueptner M, Passingham RE, Brooks DJ. Self-initiated versus externally triggered movements. II. The effect of movement predictability on regional cerebral blood flow. Brain. 2000 Jun; 123(Pt 6):1216-1228. [PubMed: 10825359]

133. Boliek CA, Rieger JM, Li SY, Mohamed Z, Kickham J, Amundsen K. Establishing a reliable protocol to measure tongue sensation. J Oral Rehabil. 2007 Jun; 34(6):433-441. [PubMed: 17518978]

134. Jacobs R, Wu CH, Van Loven K, Desnyder M, Kolenaar B, Van Steenberghed D. Methodology of oral sensory tests. J Oral Rehabil. 2002 Aug; 29(8):720-730. [PubMed: 12220338]

135. Fukunaga A, Uematsu H, Sugimoto K. Influences of aging on taste perception and oral somatic sensation. J Gerontol A Biol Sci Med Sci. 2005 Jan; 60(1):109-113. [PubMed: 15741292]

136. Kononen M, Kuikka JT, Husso-Saastamoinen M, et al. Increased perfusion in motor areas after constraint-induced movement therapy in chronic stroke: a single-photon emission computerized tomography study. J Cereb Blood Flow Metab. 2005 Dec; 25(12):1668-1674. [PubMed: 15931162] 